\title{
Analisis Peluang terhadap Penilaian Kinerja Pegawai di PT. XYZ Menggunakan Metode Regresi Linier Berganda dengan SPSS
}

\author{
Billy Nugraha*1, Wahyudin Wahyudin ${ }^{2}$, Fahriza Nurul Azizah ${ }^{3}$ \\ ${ }^{1}$ Program Studi Teknik Industri, Fakultas Teknik, Universitas Singaperbangsa Karawang, Jl. H.S. Ronggowaluyo, \\ Telukjambe Timur, Kota Karawang, 41373, Indonesia \\ ${ }^{2,3}$ Grup Riset, Universitas Singaperbangsa Karawang, Jl. H.S. Ronggowaluyo, Telukjambe Timur, Kota Karawang, \\ 41373, Indonesia \\ Email: $\underline{\text { billynugraha982@gmail.com }}{ }^{1}, \underline{\text { hwwahyudin @ gmail.com }^{2}}, \underline{\text { ahriza.azizah@yahoo.co.id }}^{3}$
}

\begin{abstract}
Abstrak
Penelitian tentang pengembangan sumber daya manusia telah banyak dilakukan. Dengan tujuan dapat dijadikan parameter untuk menciptakan pengembangan sumber daya manusia yang berkualitas. Maka penelitian ini bertujuan untuk mengetahui pengaruh peluang terhadap penilaian kinerja pegawai. Peluang yang diteliti terbagi menjadi tiga indikator, yaitu lingkungan, aturan dan rekan kerja berdasarkan teori Edi Priansa. Teknik pengambilan sampel dalam penelitian ini menggunakan sampling jenuh. Teknik analisis data dilakukan secara bertahap, mulai dari editing, coding, scoring dan tabulasi. Selain itu menggunakan skala likert yang dikembangkan oleh Ransis Likert. Metode yang digunakan dalam penelitian ini adalah regresi linier berganda. Hasil dari hipotesis t, terdapat pada nilai thitung secara parsial (berurutan) mulai dari $\mathrm{X}_{1}$ (lingkungan) $=2,639, \mathrm{X}_{2}$ (aturan) $=3,379$ dan $\mathrm{X}_{3}$ (rekan kerja) $=2,210$. Selain itu

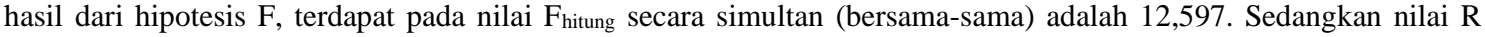
Square $\left(\mathrm{R}^{2}\right)$ sebesar 0,282, jika dipersenkan maka hasilnya 28,2\%. Dapat disimpulkan dari ketiga variabel independen berpengaruh terhadap variabel dependen sebesar $28,2 \%$. Sisa persen berkisar 71,8\% dipengaruhi oleh variabel independen lainnya, yang tidak diteliti dalam penelitian ini. Namun hal ini akan menjadi pengembangan penelitian selanjutnya.
\end{abstract}

Kata kunci: aturan kerja, lingkungan kerja, penilaian kinerja pegawai, rekan kerja

\begin{abstract}
Research on the development of human resources has been done. With the aim can be used as a parameter to create quality human resource development. So this study aims to determine the effect of opportunities for employee performance assessments. The opportunities studied are divided into three indicators, namely the environment, rules and coworkers based on Edi Priansa's theory. The sampling technique in this study uses saturated sampling. Data analysis techniques are carried out gradually, ranging from editing, coding, scoring and tabulation. In addition to using the Likert scale developed by Likert Ransis. The method used in this study is multiple linear regression. The results of the $t$ hypothesis, there are partially (sequential) $t$-count values starting from X1 (environment) $=2.639, x 2$ $($ rules $)=3.379$ and $C 3$ (coworkers $)=2.210$. In addition, the result of the $F$ hypothesis, there is a simultaneous $F$-count value (together) is 12,597 . While the value of $R$ Square $\left(R^{2}\right)$ is 0.282 , if it is received, the result is $28.2 \%$. It can be concluded from the three independent variables affect the dependent variable of $28.2 \%$. The remaining percent ranges from $71.8 \%$ to be influenced by other independent variables, which were not studied in this study. But this will be the development of further research.
\end{abstract}

Keywords: work rules, work environment, employee performance appraisal, coworkers

\section{Pendahuluan}

Perusahaan menghadapi berbagai dinamika perubahan dengan berjalannya perkembangan bisnis, lingkungan strategis dan tuntutan dari stakeholder. Perusahaan dihadapkan dengan berbagai situasi dan kondisi yang menuntut adanya fleksibilitas terhadap perubahan (Adair, 2008). Fleksibilitas yang didukung oleh sumber daya manusia yang sesuai dengan kebutuhan perusahaan dan mampu untuk bekerja dengan orientasi kepada pelanggan (Priansa, 2019). Pegawai merupakan bagian unsur yang menentukan keberhasilan perusahaan dalam mencapai tujuan (Armstrong, 2009). Perusahaan yang dikelola secara profesional sangat memahami jika pegawai mampu diberdayakan secara optimal, kinerja yang dihasilkannya pun akan optimal (Brown, 2004). Hasil penelitian terhadap pengembangan sumber daya manusia telah banyak dilakukan. Dengan tujuan hasil dari penelitian yang telah dilakukan dapat dijadikan

\footnotetext{
${ }^{*}$ Penulis korespondensi
} 
acuan atau paramater untuk menciptakan pengembangan sumber daya manusia yang berkualitas (Alderfer, 2009). Dari hasil latar belakang menyebutkan pengembangan sumber daya manusia harus terus dilakukan agar tujuan dari perusahaan dapat dicapai. Maka penelitian ini bertujuan untuk mengetahui pengaruh peluang terhadap penilaian kinerja pegawai. Peluang yang diteliti terbagi menjadi tiga indikator, yaitu lingkungan $\left(\mathrm{X}_{1}\right)$, aturan $\left(\mathrm{X}_{2}\right)$ dan rekan kerja $\left(\mathrm{X}_{3}\right)$ (Priansa, 2019). Batasan dalam penelitian ini adalah jumlah sampel yang diambil 100 orang pegawai perusahaan. Oleh sebab itu hasil pengujian didasarkan dari banyaknya jumlah sampel, yaitu hipotesis $\mathrm{t}$ dan $\mathrm{F}$ serta koefisien determinasi $\left(\mathrm{R}^{2}\right)$.

Peluang (opportunity) berkaitan dengan peluang yang dimiliki oleh pegawai (Arni, 2005). Hal ini dikarenakan adanya halangan yang menjadi rintangan dalam bekerja (As'ad, 2009). Dengan beberapa variabel seperti aturan kerja, lingkungan kerja dan rekan kerja (Priansa, 2019). Maka penelitian ini menggunakan peluang sebagai variabel independen. Masing-masing variabel independen terdiri dari: aturan kerja $\left(\mathrm{X}_{1}\right)$, lingkungan kerja $\left(\mathrm{X}_{2}\right)$ dan rekan kerja $\left(\mathrm{X}_{3}\right)$. Dengan penjelasan sebagai berikut:

a. Aturan kerja, dijadikan sebagai variabel independen dalam penelitian $\left(\mathrm{X}_{1}\right)$. Hal ini dikarenakan aturan kerja merupakan prioritas yang ditetapkan perusahaan. Semua pegawai perlu mengikuti segala aturan yang diberikan (Sastrohadiwiryo, 2001). Maka dari itu untuk mengetahui pengaruh aturan kerja terhadap penilaian kinerja pegawai.

b. Lingkungan kerja, dijadikan sebagai variabel independen dalam penelitian $\left(\mathrm{X}_{2}\right)$. Lingkungan merupakan faktor eksternal yang dirasakan pegawai ketika bekerja. Lingkungan yang mendukung akan menghasilkan pekerjaan yang sesuai harapan perusahaan (Shermon, 2005). Maka dari itu untuk mengetahui pengaruh lingkungan kerja terhadap penilaian kinerja pegawai.

c. Rekan kerja, dijadikan sebagai variabel independen dalam penelitian $\left(\mathrm{X}_{3}\right)$. Rekan kerja merupakan faktor internal yang dirasakan pegawai ketika bekerja. Hal ini dikarenakan rekan kerja dapat memengaruhi hasil kerja sama (team work) yang sesuai harapan perusahaan (Sikula, 2001). Maka dari itu untuk mengetahui pengaruh rekan kerja terhadap penilaian kinerja pegawai.

Penilaian kinerja pegawai mengacu pada sistem formal dan terstruktur yang dapat digunakan untuk mengukur, menilai dan memengaruhi sifat pekerjaan (Priansa, 2019). Pegawai memerlukan umpan balik atas hasil pekerjaan sebagai motivasi di masa yang akan datang (Rivai \& Sagala, 2009). Selain itu penilaian kinerja pegawai merupakan suatu tahapan yang terdiri dari: identifikasi, pengukuran dan manajemen (Mejia, et al., 2012). Maka indikator yang akan diukur, dinilai dan dipengaruhi sesuai dengan kebutuhan perusahaa. Pada penelitian ini menggunakan penilaian kinerja pegawai sebagai variabel dependen (Y). Sementara peluang dijadikan variabel independen $(\mathrm{X})$, yang terdiri dari aturan kerja (X1), lingkungan kerja (X2) dan rekan kerja (X3).

Berikut beberapa penelitian terdahulu yang dijadikan parameter dalam penelitian ini. Penelitian yang dilakukan oleh Neng Murialti dan Reza Romanda: Dari ketiga variabel tersebut jumlah tenaga kerja berhubungan positif dan signifikan (Murialti \& Romanda, 2020). Penelitian yang dilakukan oleh Zefriyenni, Emil Salim dan Sinta Wahana: Metode pengumpulan data menggunakan survei dan menyebarkan kuesioner, dengan sampel berjumlah 89 responden (Zefriyenni, et al., 2020). Penelitian yang dilakukan oleh Fauzhia Rahmasari: Analisis regresi adalah teknik analisis data dalam statistika yang digunakan untuk menganalisis hubungan antara beberapa variabel independen dengan variabel dependen (Rahmasari, 2020). Penelitian yang dilakukan oleh Endang Setyowati dan Mashuri: Pengolahan data menggunakan metode analisis regresi dengan bantuan SPSS (Setyowati \& Mashuri, 2020). Penelitian yang dilakukan oleh Sapto Priyanto dan Ajeng Tyas Damayanti: Pengumpulan data dilakukan dengan pengedaran kuesioner kepada 150 responden dengan teknik random sampling (Priyanto \& Damayanti, 2020).

Sedangkan beberapa penelitian terdahulu lainnya dijadikan sebagai alternatif parameter dalam penelitian ini. Penelitian yang dilakukan oleh Nopitasari Daulay dan Hikmah: Teknik pengambilan sampel dengan menggunakan metode sampling jenuh (Daulay \& Hikmah, 2020). Penelitian yang dilakukan oleh Rahma Gusmawati Tammu: Metode penelitian menggunakan metode kuantitatif untuk menjelaskan hubungan kausal (causal relationship) antara beberapa variabel (Tammu, 2020). Penelitian yang dilakukan oleh Randy Sonhadi, Serlin Serang dan Roslina Alam: Penelitian tersebut menggunakan data kuesioner dan observasi dengan teknik analisis data: analisis deskriptif, uji validitas, uji reliabilitas, regresi linier berganda dan hipotesis (Sonhadi, et al., 2020). Penelitian yang dilakukan oleh Liawati: Sampel yang digunakan sebanyak 172 responden (Liawati, 2020). Penelitian yang dilakukan oleh Nurul Fauziyah dan Novi Vizainiyah: Teknik pengumpalan sampel menggunakan purposive sampling (Fauziyah \& Vizainiyah, 2020). Dari hasil kajian terhadap beberapa penelitian di atas menggunakan teknik analisis atau metode penelitian regresi linier berganda. Namun hasil penelitian dilakukan regresi linier berganda, tanpa dilakukan uji asumsi klasik terlebih dahulu. Sedangkan syarat-syarat dalam uji asumsi klasik adalah data yang digunakan harus memenuhi asumsi-asumsi klasik. Seperti asumsi normalitas, homogenitas, multikolinearitas, linearitas dan heteroskedastisitas (Riadi, 2016). Maka penelitian yang menjadi acuan 
berdasarkan dari: (Rahmasari, 2020; Sonhadi, et al., 2020).

Gap penelitian ini berdasarkan dari beberapa penelitian terdahulu di atas. Dapat diketahui penelitian terdahulu yang belum menggunakan uji asumsi klasik secara keseluruhan. Sehingga perlu dilakukan penelitian ini untuk mengetahui pengujian berdasarkan Edi Riadi. Hal ini bertujuan untuk mengetahui seberapa besar signifikansi atau keberartian makna suatu pengujian. Maka hal ini dijadikan sebagai penyempurnaan atau ketepatan dari penelitian terdahulu. Sedangkan untuk pengembangan penelitian ini berdasarkan teknik analisis data yang digunakan pada metode penelitian. Penelitian ini akan menggunakan tahap analisis kuantitatif, terdiri dari: uji validitas dan reliabilitas. Selanjutnya uji asumsi klasik, terdiri dari: uji normalitas, homogenitas, multikolinearitas, linearitas dan heteroskedastisitas. Maka sebagai tahap pengambilan hipotesis berdasarkan uji analisis regresi linier berganda, yaitu hipotesis t dan F. Selain itu didapatkan juga nilai koefisien determinasi untuk mengetahui sebesar besar variabel yang diteliti.

\section{Metode Penelitian}

Objek kajian dalam penelitian dilakukan di PT. XYZ. Perusahaan yang bergerak dibidang produksi cairan kimia, berlokasi di Kawasan Industri Kujang Cikampek. Responden penelitian ini adalah seluruh pegawai yang bekerja di PT. XYZ. Selanjutnya tahapan pengumpulan data menggunakan kuesioner secara online. Pengembangan kuesioner dilakukan berdasarkan kajian literatur sebelumnya. Selain itu didukung dari pernyataan Ransis Likert, karena menggunakan skala likert sebagai instrumen dalam penelitian ini. Teknik pengambilan sampel dalam penelitian ini menggunakan sampling jenuh. Sampling jenuh merupakan teknik pengambilan sampel jika semua populasi digunakan sebagai sampel. Selain itu termasuk dalam nonprobability sampling. Teknik analisis data dalam penelitian ini dilakukan secara bertahap, mulai dari editing, coding, scoring dan tabulasi. Dalam penelitian ini menggunakan skala likert yang dikembangkan oleh Ransis Likert. Tujuan dari skala ini untuk mengetahui tingkat penilaian kinerja pegawai dengan menentukan skor pada setiap pertanyaan atau indikator dalam peluang. Untuk kerangka berpikir dalam penelitian ini, seperti pada Gambar 1. di bawah ini:

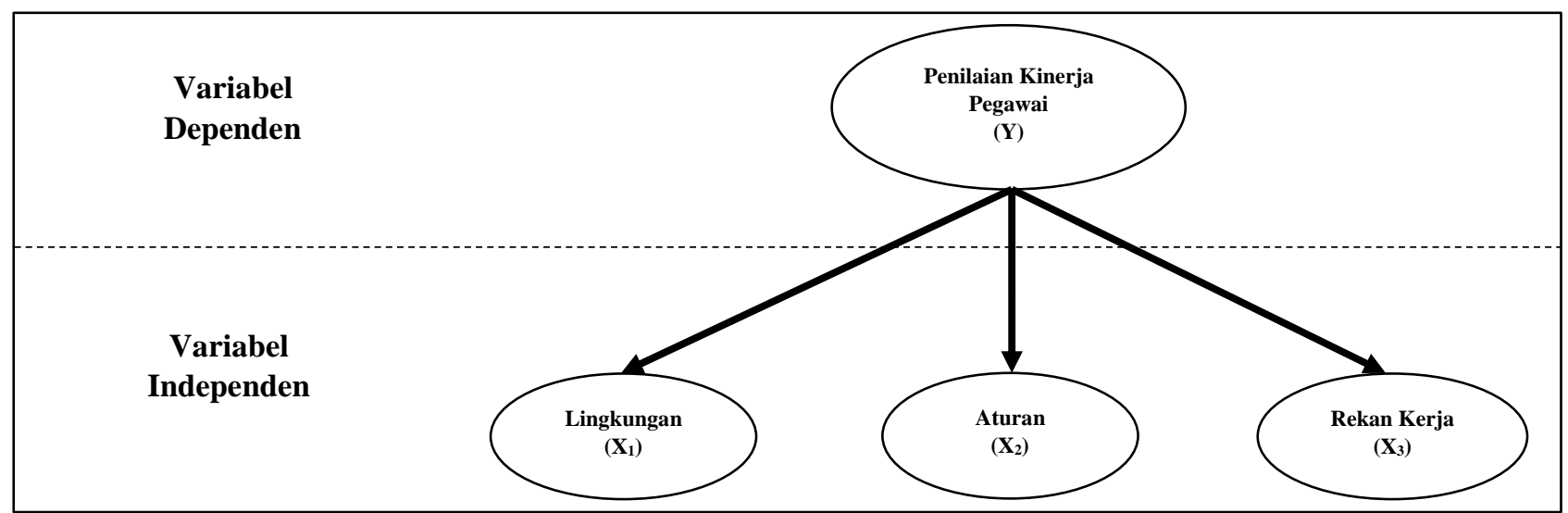

Gambar 1. Kerangka Berpikir Penelitian

Metode yang digunakan dalam penelitian ini analisis regresi linier berganda. Hasil akhir dari metode ini menghasilkan hipotesis dan koefisien determinasi $\left(\mathrm{R}^{2}\right)$. Hipotesis dan koefisien determinasi $\left(\mathrm{R}^{2}\right)$ sebagai pengambilan keputusan dalam penelitian ini. Selain itu dalam pengembangan penelitian yang menggunakan metode statiistik, dilakukan penyempurnaan dari beberapa penelitian terdahulu. Analisis regresi diartikan sebagai analisis tentang hubungan suatu variabel kepada variabel lain. Dengan kata lain yaitu variabel bebas dalam rangka membuat estimasi atau prediksi dari nilai rata-rata variabel terikat dengan diketahuinya nilai variabel bebas (Riadi, 2016). Sebelum dilakukan analisis regresi linier berganda dilakukan uji asumsi klasik. Syarat-syarat dalam uji asumsi klasik merupakan data yang digunakan harus memenuhi asumsi klasik. Seperti asumsi normalitas, homogenitas, multikolinearitas, linearitas dan heteroskedastisitas (Riadi, 2016). Maka untuk pengembangan penelitian yang menggunakan metode statistik. Perlu memenuhi syarat-syarat uji asumsi klasik sebelum dilakukan uji regresi linier berganda. Hal ini bertujuan untuk mengetahui seberapa besar signifikansi atau keberartian makna suatu pengujian. Berikut pengujian yang akan dilakukan dalam penelitian ini, seperti pada Gambar 2. di bawah ini: 


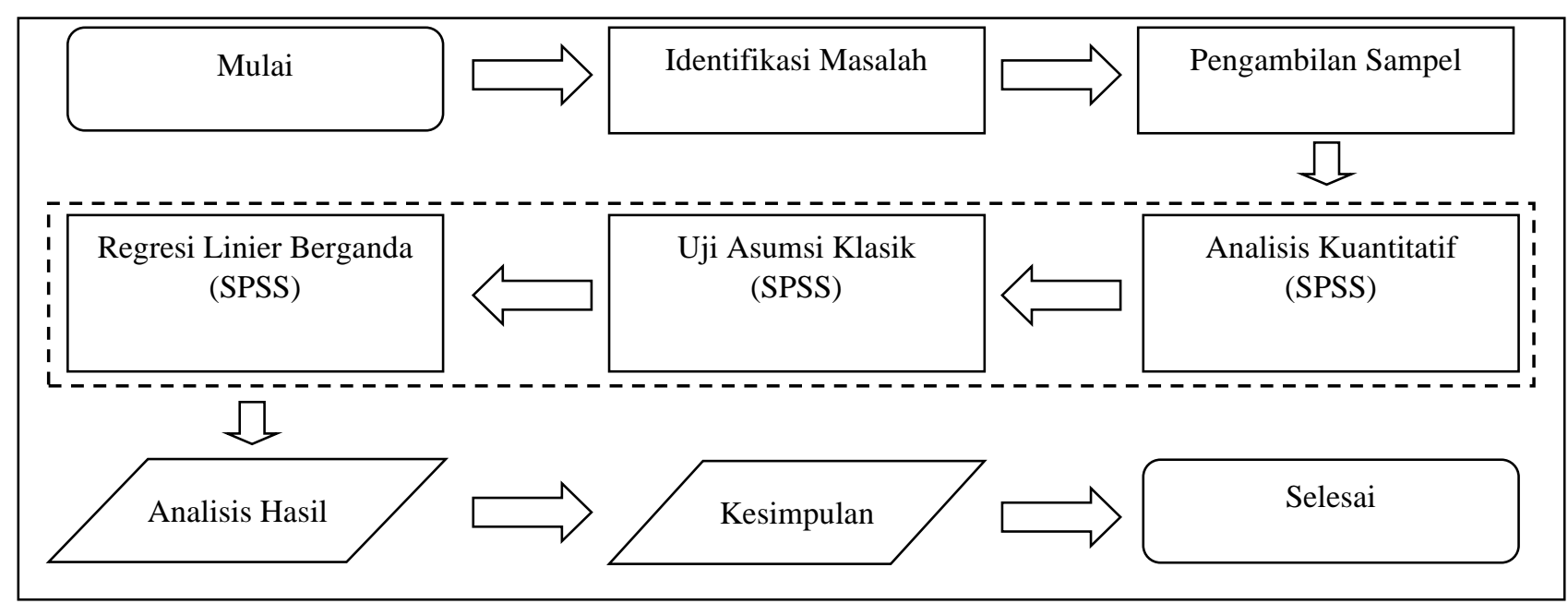

Gambar 2. Model Pengujian Regresi Linier Berganda dengan Mempertimbangkan Uji Asumsi Klasik

\section{Hasil dan Pembahasan}

Jumlah sampel yang digunakan dalam penelitian ini berjumlah 100 responden. Seluruh responden merupakan pegawai di PT. XYZ. Maka teknik pengambilan sampel dalam penelitian ini menggunakan sampling jenuh. Beriku beberapa hasil identitas responden di PT. XYZ:

a. Gambaran umum responden berdasarkan jenis kelamin. Berdasarkan hasil penelitian, diperoleh gambaran tentang jenis kelamin dari responden yang dapat dilihat pada Gambar 3. di bawah ini:

\section{$\underline{\text { Responden Berdasarkan Jenis Kelamin }}$}

Perempuan

11

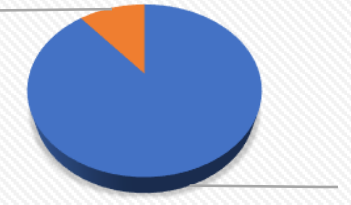

Laki-Laki

89

- Laki-Laki $\quad$ Perempuan

Gambar 3. Responden Berdasarkan Jenis Kelamin

Maka dari Gambar 3. di atas, jumlah 100 responden berdasarkan jenis kelamin. Untuk jenis kelamin laki-laki sebanyak 89 responden. Sedangkan untuk jenis kelamin perempuan sebanyak 11 responden. Seluruh responden merupakan pegawai di PT. XYZ.

b. Gambaran umum responden berdasarkan tingkat pendidikan. Berdasarkan hasil penelitian, diperoleh gambaran tentang tingkat pendidikan dari responden yang dapat dilihat pada Gambar 4. di bawah ini:

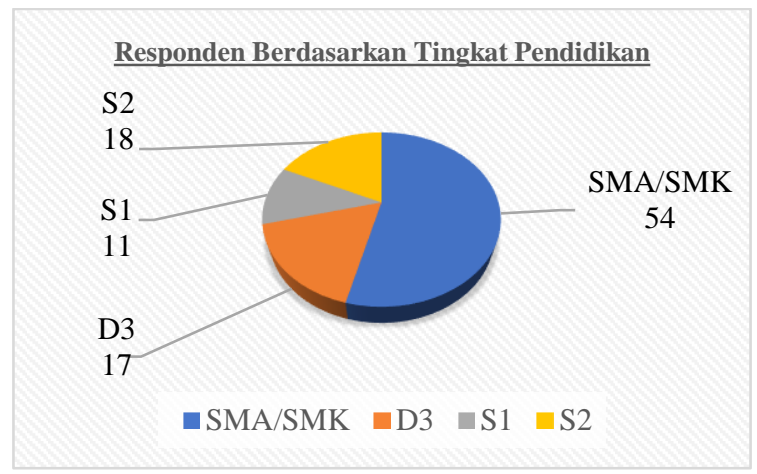

Gambar 4. Responden Berdasarkan Tingat Pendidikan

Maka dari Gambar 4. di atas, jumlah 100 responden berdasarkan tingkat pendidikan. Untuk tingkat pendidikan SMA/SMK sebanyak 54 responden. Untuk tingkat pendidikan D3 sebanyak 17 responden. Untuk tingkat pendidikan S1 sebanyak 11 responden. Sedangkan untuk tingkat pendidikan S2 sebanyak 18 responden. Seluruh responden merupakan pegawai di PT. XYZ.

c. Gambaran umum responden berdasarkan status pekerjaan. Berdasarkan hasil penelitian, diperoleh gambaran tentang status pekerjaan dari responden yang dapat dilihat pada Gambar 5. di bawah ini:

\section{$\underline{\text { Responden Berdasarkan Status Pekerjaan }}$}

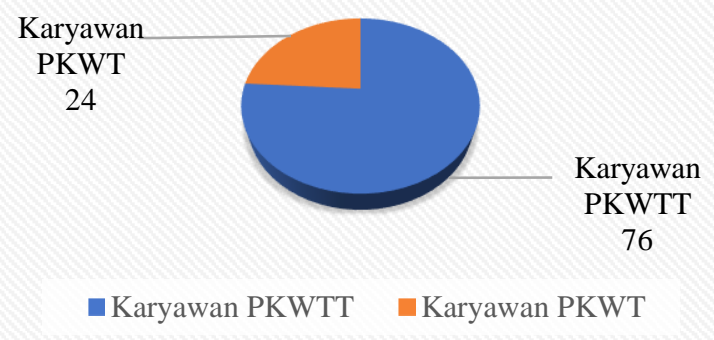

Gambar 5. Responden Berdasarkan Status Pekerjaan

Maka dari Gambar 5. di atas, jumlah 100 responden berdasarkan status pekerjaan. Untuk status pekerjaan PKWTT sebanyak 76 responden. Sedangkan untuk status pekerjaan PKWT sebanyak 
24 responden. Seluruh responden merupakan pegawai di PT. XYZ.

\subsection{Uji Validitas}

Uji validitas termasuk dalam uji pertama di analisis kuantitatif. Uji validitas, akan menguji masing-masing variabel/indikator yang dijadikan dalam penelitian ini.
Keseluruhan variabel/indikator penelitian memuat 4 pertanyaan yang harus dijawab oleh responden. Uji validitas ini bertujuan untuk menunjukkan sejauh mana instrumen pengukuran mampu mengukur apa yang akan diukur (Santosa \& Ashari, 2005). Uji Validitas menggunakan pearson product moment yang dibantu oleh program software SPSS. Berikut hasil pengujian uji validitas pada Tabel 1. di bawah ini:

Tabel 1. Hasil Uji Validitas

\begin{tabular}{ccccc}
\hline No. & Indikator & Nilai rhing $_{\text {Nilai }}$ & Nabel & Keterangan \\
\hline 1 & Lingkungan $\left(\mathrm{X}_{1}\right)$ & 0,614 & 0,1966 & Valid \\
2 & Aturan $\left(\mathrm{X}_{2}\right)$ & 0,655 & 0,1966 & Valid \\
3 & Rekan Kerja $\left(\mathrm{X}_{3}\right)$ & 0,568 & 0,1966 & Valid \\
4 & Penilaian Kinerja Pegawai $(\mathrm{Y})$ & 0,867 & 0,1966 & Valid \\
\hline
\end{tabular}

Pada Tabel 1. di atas diperoleh bahwa semua indikator yang digunakan untuk mengukur variabelvariabel. Variabel digunakan dalam penelitian ini mempunyai koefisien korelasi yang lebih besar dari $r$ tabel = 0,1966 (didapatkan dari nilai $r$ tabel). Maka semua indikator dalam variabel tersebut adalah valid dan layak untuk dilakukan uji selanjutnya dalam penelitian.
Uji reliabilitas termasuk dalam uji kedua di analisis kuantitatif. Uji reliabilitas, menggunakan cronbach alpha yang dibantu oleh program software SPSS. Uji reliabilitas ini bertujuan untuk menunjukkan konsistensi dari alat ukur dalam mengukur gejala yang sama dilain kesempatan (Santosa \& Ashari, 2005). Berikut hasil pengujian uji reliabilitas pada Tabel 2. di bawah ini:

\subsection{Uji Reliabilitas}

Tabel 2. Hasil Uji Reliabilitas

\begin{tabular}{ccccc}
\hline No. & Indikator & Nilai Hitung & Nilai Tabel & Keterangan \\
\hline 1 & Lingkungan $\left(\mathrm{X}_{1}\right)$ & 0,765 & 0,60 & Reliabel \\
2 & Aturan $\left(\mathrm{X}_{2}\right)$ & 0,765 & 0,60 & Reliabel \\
3 & Rekan Kerja $\left(\mathrm{X}_{3}\right)$ & 0,765 & 0,60 & Reliabel \\
4 & Penilaian Kinerja Pegawai $(\mathrm{Y})$ & 0,765 & 0,60 & Reliabel \\
\hline
\end{tabular}

Pada Tabel 2. di atas menunjukkan semua variabel mempunyai nilai cronbach alpha yang cukup besar yaitu di atas 0,60. Sehingga dapat dikatakan semua konsep pengukur masing-masing variabel dari kuisioner adalah reliabel. Maka untuk selanjutnya item pada masingmasing konsep variabel tersebut layak digunakan sebagai alat ukur.

\subsection{Uji Normalitas}

Uji normalitas termasuk dalam uji pertama di uji asumsi klasik. Uji normalitas, menggunakan kolmogorov smirnov yang dibantu oleh program software SPSS. Uji normalitas ini bertujuan untuk mengetahui bahwa data berdistribusi normal atau tidak. Maksud dari data berdistribusi normal adalah bahwa data akan mengikuti bentuk dari distribusi normal. Distribusi normal data dengan bentuk distribusi normal dimana data memusat pada nilai rata-rata dan nilai tengah (Santosa \& Ashari, 2005). Berikut hasil pengujian uji normalitas pada Tabel 3. di bawah ini:

Tabel 3. Hasil Uji Normalitas

\begin{tabular}{ccccc}
\hline No. & Indikator & Nilai Hitung & Taraf Signifikansi & Keterangan \\
\hline 1 & Lingkungan $\left(\mathrm{X}_{1}\right)$ & 0,092 & 0,05 & Normal \\
2 & Aturan $\left(\mathrm{X}_{2}\right)$ & 0,092 & 0,05 & Normal \\
3 & Rekan Kerja $\left(\mathrm{X}_{3}\right)$ & 0,092 & 0,05 & Normal \\
4 & Penilaian Kinerja Pegawai $(\mathrm{Y})$ & 0,092 & 0,05 & Normal \\
\hline
\end{tabular}

Pada Tabel 3. di atas menunjukkan semua variabel mempunyai nilai kolmogorov smirnov yang sama pervariabel. Semuanya melebihi dari taraf signifikansi yang dijadikan sebagai penentuan hipotesis. Sehingga dapat disimpulkan bahwa data tersebut berdistribusi normal dan layak untuk dilakukan uji selanjutnya.

\subsection{Uji Homogenitas}

Uji homogenitas termasuk dalam uji kedua di uji asumsi klasik. Uji homogenitas, menggunakan LEVENE yang dibantu oleh program software SPSS. Uji homogenitas untuk menujukkan bahwa perbedaan yang terjadi pada uji statistik parametrik benar-benar terjadi akibat adanya perbedaan antar kelompok, bukan sebagai akibat perbedaan dalam kelompok (Riadi, 2016). Berikut hasil pengujian uji homogenitas pada Tabel 4. di bawah ini: 
Tabel 4. Hasil Uji Homogenitas

\begin{tabular}{ccccc}
\hline No. & Indikator & Nilai Hitung & Taraf Signifikansi & Keterangan \\
\hline 1 & Lingkungan $\left(\mathrm{X}_{1}\right)$ & 0,051 & 0,05 & Homogen \\
2 & Aturan $\left(\mathrm{X}_{2}\right)$ & 0,051 & 0,05 & Homogen \\
3 & Rekan Kerja $\left(\mathrm{X}_{3}\right)$ & 0,051 & 0,05 & Homogen \\
4 & Penilaian Kinerja Pegawai $(\mathrm{Y})$ & 0,051 & 0,05 & Homogen \\
\hline
\end{tabular}

Pada Tabel 4. di atas menunjukkan semua variabel mempunyai nilai $L E V E N E$ yang sama per-variabel dan melebihi taraf signifikansi. Sehingga dapat disimpulkan bahwa data tersebut homogen dan layak untuk dilakukan uji selanjutnya.

\subsection{Uji Multikolinearitas}

Uji multikolinearitas termasuk dalam uji ketiga di uji asumsi klasik. Uji multikolinearitas, menggunakan varian inflation factor yang dibantu oleh program software SPSS. Uji multikolinearitas untuk menyatakan bahwa variabel independen harus terbebas dari gejala multikolinearitas. Gejala multikolinearitas adalah gejala kolerasi antar variabel independen. Gejala ini ditujukkan dengan kolerasi yang signifikan antar variabel independen. Jika terjadi gejala multikolinearitas, salah satu langkah untuk memperbaiki model adalah dengan menghilangkan variabel dari model regresi. Sehingga bisa dipilih model yang paling baik (Santosa \& Ashari, 2005). Berikut hasil pengujian uji multikolinearitas pada Tabel 5. di bawah ini:

Tabel 5. Hasil Uji Multikolinearitas

\begin{tabular}{ccccc}
\hline No. & Indikator & Nilai Hitung & Taraf Signifikansi & Keterangan \\
\hline 1 & Lingkungan $\left(\mathrm{X}_{1}\right)$ & 1,120 & 10,00 & Tidak Terdapat Multikolinearitas \\
2 & Aturan $\left(\mathrm{X}_{2}\right)$ & 1,143 & 10,00 & Tidak Terdapat Multikolinearitas \\
3 & Rekan Kerja $\left(\mathrm{X}_{3}\right)$ & 1,057 & 10,00 & Tidak Terdapat Multikolinearitas \\
\hline
\end{tabular}

Pada Tabel 5. di atas menunjukkan semua variabel mempunyai nilai varian inflation factor yang berbeda per-variabel dan kurang dari nilai taraf signifikansi. Sehingga dapat disimpulkan bahwa data tersebut tidak terjadi multikolinearitas dan layak untuk dilakukan uji selanjutnya.

\subsection{Uji Linearitas}

Uji linearitas termasuk dalam uji keempat di uji asumsi klasik. Uji Linearitas, menggunakan deviation from linearity yang dibantu oleh program software SPSS. Uji linearitas untuk menyatakan bahwa untuk setiap persamaan regresi linier. Hubungan antar variabel independen dengan dependen yang harus linear. Asumsi ini akan menentukan jenis persamaan estimasi yang digunakan, apakah persamaan logaritma, persamaan kubik, kuadratik atau inverse (Santosa \& Ashari, 2005). Berikut hasil pengujian uji linearitas pada Tabel 6. di bawah ini:

Tabel 6. Hasil Uji Linearitas

\begin{tabular}{ccccc}
\hline No. & Indikator & Nilai Hitung & Taraf Signifikansi & Keterangan \\
\hline 1 & Lingkungan $\left(\mathrm{X}_{1}\right)$ & 0,067 & 0,05 & Linear \\
2 & Aturan $\left(\mathrm{X}_{2}\right)$ & 0,253 & 0,05 & Linear \\
3 & Rekan Kerja $\left(\mathrm{X}_{3}\right)$ & 0,529 & 0,05 & Linear \\
\hline
\end{tabular}

Pada Tabel 6. di atas menunjukkan semua variabel mempunyai nilai deviation from linearity yang berbeda per-variabel dan melebihi taraf signifikansi. Sehingga dapat disimpulkan bahwa data tersebut linear dan layak untuk dilakukan uji selanjutnya.

\subsection{Uji Heteroskedastisitas}

Uji heteroskedastisitas termasuk dalam uji kelima di uji asumsi klasik. Uji Heteroskedastisitas, menggunakan rank spearman yang dibantu oleh program software SPSS. Uji heteroskedastisitas untuk menyatakan dalam regresi dimana varian dari residual tidak sama untuk satu pengamatan ke pengamatan lain. Dalam regresi, salah satu asumsi yang harus dipenuhi adalah bahwa varian dari residual dari satu pengamatan ke pengamatan yang lain tidak memiliki pola tertentu. Pola yang tidak sama ini ditunjukkan dengan nilai yang tidak sama antar satu varian dari residual. Gejala yang tidak sama ini disebut dengan gejala heteroskedastisitas (Santosa \& Ashari, 2005). Berikut hasil pengujian uji heteroskedastisitas pada Tabel 7. di bawah ini:

Tabel 7. Hasil Uji Heteroskedastisitas

\begin{tabular}{ccccc}
\hline No. & Indikator & Nilai Hitung & Taraf Signifikansi & Keterangan \\
\hline 1 & Lingkungan $\left(\mathrm{X}_{1}\right)$ & 1,000 & 0,05 & Tidak Terdapat Heteroskedastisitas \\
2 & Aturan $\left(\mathrm{X}_{2}\right)$ & 1,000 & 0,05 & Tidak Terdapat Heteroskedastisitas \\
3 & Rekan Kerja $\left(\mathrm{X}_{3}\right)$ & 1,000 & 0,05 & Tidak Terdapat Heteroskedastisitas \\
\hline
\end{tabular}

Pada Tabel 7. di atas menunjukkan semua variabel mempunyai nilai rank spearman yang berbeda pervariabel dan melebihi taraf signifikansi. Sehingga dapat disimpulkan bahwa data tersebut tidak terjadi heteroskedastisitas dan layak untuk dilakukan uji selanjutnya. 


\subsection{Uji Regresi Linear Berganda}

Hipotesis yang diambil berdasarkan hasil dari hipotesis $t$ dan hipotesis F. Selain itu untuk mengetahui berapa persen dari variabel independen yang diteliti didapat dari nilai koefisien determinasi $\left(\mathrm{R}^{2}\right)$. Berikut hasil pengujian regresi linier berganda pada Tabel 8. di bawah ini:

Tabel 8. Hasil Uji Regresi Linear Berganda

\begin{tabular}{ccccc}
\hline No. & Indikator & Nilai thitung & Nilai Tabel & Keterangan \\
\hline 1 & Lingkungan $\left(\mathrm{X}_{1}\right)$ & 2,639 & 1,984 & Terdapat Pengaruh Signifikan \\
2 & Aturan $\left(\mathrm{X}_{2}\right)$ & 3,379 & 1,984 & Terdapat Pengaruh Signifikan \\
3 & Rekan Kerja $\left(\mathrm{X}_{3}\right)$ & 2,210 & 1,984 & Terdapat Pengaruh Signifikan \\
\hline & Fhitung & 12,597 & 2,700 & Terdapat Pengaruh Signifikan \\
\hline & Koefisien Determinasi $\left(\mathrm{R}^{2}\right)$ & $28,2 \%$ & - & - \\
\hline
\end{tabular}

Penjelasan pada masing-masing nilai hipotesis $t$ dan hipotesis F serta koefisien determinasi $\left(\mathrm{R}^{2}\right)$. Hasil hipotesis $t$ secara berurutan dari lingkungan $\left(\mathrm{X}_{1}\right)=2,639$, aturan $\left(\mathrm{X}_{2}\right)=3,379$ dan rekan kerja $\left(\mathrm{X}_{3}\right)=2,210$. Hal ini dilakukan secara parsial atau per-variabelnya. Dari hasil penelitian yang telah dilakukan ketiga variabel independen secara parsial tersebut terdapat pengaruh signifikan terhadap variabel dependen. Hal ini didasarkan dari:

a. H0 diterima jika nilai $t_{\text {hitung }}>$ nilai $t_{\text {tabel}}$, maka terdapat pengaruh.

b. HO ditolak jika nilai $t_{\text {hitung }}<$ nilai $t_{\text {tabel }}$, maka tidak terdapat pengaruh.

Dapat disimpulkan bahwa ketiga nilai variabel independen atau $t_{\text {hitung }}>$ nilai $t_{\text {tabel }}$, maka terdapat pengaruh signifikan terhadap variabel dependen. Sedangkan nilai hipotesis F secara simultan $(X)=12,597$. Hal ini dilakukan secara simultan dari ketiga variabel independen terhadap variabel dependen. Begitu pula hasil penelitian yang telah dilakukan ketiga variabel independen secara simultan tersebut terdapat pengaruh signifikan terhadap variabel dependen. Hal ini didasarkan dari:

a. H0 diterima jika nilai $F_{\text {hitung }}>$ nilai $F_{\text {tabel }}$, maka terdapat pengaruh.

b. H0 ditolak jika nilai $F_{\text {hitung }}<$ nilai $F_{\text {tabel }}$, maka tidak terdapat pengaruh.

Dapat disimpulkan bahwa ketiga nilai variabel independen atau $\mathrm{F}_{\text {hitung }}>$ nilai $\mathrm{F}_{\text {tabel, }}$, maka terdapat pengaruh signifikan terhadap variabel dependen. Sementara itu nilai koefisien determinasi $\left(\mathrm{R}^{2}\right)$ dalam penelitian ini sebesar 28,2\%. Hasil tersebut untuk mengetahui sebesar besar tingkat pengaruh penelitian yang telah dilakukan.

\section{Kesimpulan}

Pengambilan keputusan secara hipotesis $t$ yang dilakukan secara parsial terhadap ketiga variabel independen. Maka variabel lingkungan $\left(\mathrm{X}_{1}\right)$, aturan $\left(\mathrm{X}_{2}\right)$ dan rekan kerja $\left(\mathrm{X}_{3}\right)$ berpengaruh secara singnifikan terhadap penilaian kinerja pegawai. Hal ini berdasarkan nilai $t_{\text {hitung }}>$ dari nilai $t_{\text {tabel. }}$. Sedangkan pengambilan keputusan secara hipotesis F yang dilakukan secara simultan terhadap ketiga variabel independen. Maka variabel lingkungan $\left(\mathrm{X}_{1}\right)$, aturan $\left(\mathrm{X}_{2}\right)$ dan rekan kerja $\left(\mathrm{X}_{3}\right)$ berpengaruh secara singnifikan terhadap penilaian kinerja pegawai. Hal ini berdasarkan nilai $F_{\text {hitung }}>$ dari nilai $F_{\text {tabel. }}$. Hasil dari hipotesis $t$, terdapat pada nilai $t_{\text {hitung }}$ secara parsial (berurutan) mulai dari $\mathrm{X}_{1}$ (lingkungan) =
2,639, $X_{2}($ aturan $)=3,379$ dan $X_{3}($ rekan kerja $)=2,210$. Selain itu hasil dari hipotesis $F$, terdapat pada nilai $F_{\text {hitung }}$ secara simultan (bersama-sama) adalah 12,597.

Sementara hasil pengaruh tingkat penelitian yang dilakukan sebesar 28,2\%. Hal ini berdasarkan hasil perhitungan yang diperoleh dari nilai koefisien determinasi $\left(\mathrm{R}^{2}\right)$. Dapat disimpulkan dari ketiga variabel independen berpengaruh terhadap variabel dependen sebesar $28,2 \%$. Sisa persen berkisar 71,8\% dipengaruhi oleh variabel independen lainnya, yang tidak diteliti dalam penelitian ini. Namun hal ini akan menjadi pengembangan penelitian selanjutnya. Oleh sebab itu saran yang diberikan untuk penelitian selanjutnya lebih memperbanyak kembali variabel independen dan jumlah responden yang diteliti. Namun dengan tetap mempertimbangkan uji asumsi klasik, sebelum dilakukannnya regresi linier berganda. Hal ini bertujuan untuk mengetahui seberapa besar tingkat signifikansi atau keberartian makna suatu pengujian yang dilakukan.

\section{Ucapan Terima Kasih}

Ucapan salam dan terima kasih ditujukkan kepada Rektor Universitas Singaperbangsa Karawang, Dekan Fakultas Teknik dan Koordinator Program Studi S-1 Teknik Industri. Selain itu PT. XYZ yang telah memberikan izin dan dukungan untuk selesainya penelitian ini.

\section{Daftar Pustaka}

Adair, J., 2008. Kepemimpinan yang Memotivasi. 1st ed. Jakarta: PT. Gramedia Pustaka Utama.

Alderfer, C. P., 2009. An Empirical Test of a New Theory of Human Needs. Organizational Behaviour and Human Performance, IV(2), pp. 142-175.

Armstrong, M., 2009. Armstrong's Handbook of Human Resource Management Practice. 11th ed. United Kingdom: Kogan Page.

Arni, M., 2005. Komunikasi Organisasi. 1st ed. Jakarta: Bumi Aksara.

As'ad, M., 2009. Psikologi Industri. 1st ed. Yogyakarta: Liberty.

Brown, R., 2004. Leadership. 1st ed. England: Kogan Page.

Daulay, N. \& Hikmah, 2020. Pengaruh Motivasi dan Lingkungan Kerja terhadap Kinerja Karyawan PT. Poetra Jaya Sukses Mandiri di Batam. Jurnal Kajian Manajemen Bisnis, IX(1), pp. 13-18. 
Fauziyah, N. \& Vizainiyah, N., 2020. Pengaruh Nilai Tukar dan Stabilitas terhadap Harga Saham (Studi pada Perusahaan Food and Beverage di BEI Tahun 2009-2018). Journal of Management and Accounting (J-MACC), III(1), pp. 1-10.

Liawati, 2020. Pengaruh Disiplin Kerja dan Kepuasan Kerja terhadap Prestasi Kerja Pegawai pada Kementrian Riset Teknologi dan Pendidikan Tinggi (PUSPITEK) Serpong Tangerang. Jurnal Ekonomi Efektif, II(2), pp. 235-242.

Mejia, G., R., L., Balkin, D. B. \& Cardy, R. L., 2012. Managing Human Resources. 1st ed. New Jersey: Pearson Education.

Murialti, N. \& Romanda, R., 2020. Analisis Tingkat Partisipasi Angkatan Kerja di Propinsi Bengkulu (2010-2019). Jurnal Akuntansi \& Ekonomika, X(1), pp. 109-118.

Priansa, D. J., 2019. Pengembangan dan Pelatihan SDM Perusahaan. 1st ed. Bandung: Simbiosa Rekatama Media.

Priyanto, S. \& Damayanti, A. T., 2020. Pengaruh Variabel dalam Customer Experience, Service Experience dan Prestise terhadap Frekuensi Perjalanan Penumpang (Studi Kasus pada Kereta Priority Lintas Jakarta-Bandung). Jurnal Perkeretaapian Indonesia, IV(1), pp. 56-64.

Rahmasari, F., 2020. Pengaruh Langkah Pembuata terhadap Optimasi Ketebalan Kertas Menggunakan Mesin Daur Ulang. Jurnal ASIIMETRIK: Jurnal Ilmiah Rekayasa \& Inovasi, II(1), pp. 9-17.

Riadi, E., 2016. Statistika Penelitian (Analisis Manual dan IBM SPSS). 1th ed. Yogyakarta: ANDI.

Rivai, V. \& Sagala, E. J., 2009. Manajemen Sumber Daya Manusia untuk Perusahaan: Dari Teori ke Praktik. 1st ed. Jakarta: PT. Raja Grafindo Persada.

Santosa, P. B. \& Ashari, 2005. Analisis Statistik dengan Microsoft Excel \& SPSS. 2nd ed. Yogyakarta: ANDI.

Sastrohadiwiryo, B. S., 2001. Manajemen Tenaga Kerja Indonesia. 1st ed. Bandung: CV. Pustaka Setia.

Setyowati, E. \& Mashuri, 2020. Analisis Pengaruh Luas Penggunaan Lahan dan Tinggi Tempat terhadap Produksi Padi di Kabupaten Semarang Tahun 2018. Semarang, Jurusan Matematika, Universitas Negeri Semarang, pp. 199-210.

Shermon, K., 2005. Human Behaviour at Work. 1st ed. New York: McGraw-Hill.

Sikula, A., 2001. Sistem Manajemen Kinerja. Edisi Terjemahan ed. Jakarta: Gramedia Pustaka Umum.

Sonhadi, R., Serang, S. \& Alam, R., 2020. Pengaruh Keseimbangan Kehidupan Kerja, Komitmen Organisasi dan Keterkaitan Pegawai terhadap Kinerja Pegawai pada Kantor Pelayanan Pajak (KPP) Pratama di Wilayah Kota Makassar. Paradoks: Jurnal Ilmu Ekonomi, III(2), pp. 76-85.

Tammu, R. G., 2020. Pengaruh Inflasi dan Suku Bunga Bank Indonesia terhadap Indeks Harga Saham Gabungan (IHSG) Periode 2014 - 2018. Jurnal of Economic, Management, and Accounting (JEMMA), III(1), pp. 62-66.

Zefriyenni, Salim, E. \& Wahana, S., 2020. Pengaruh Promosi, Komunikasi dan Kepercayaan terhadap Pengambilan Keputusan dalm Menjalankan E-
Commerce Networking Business di Kota Padang (Study Kasus Mahasiswa Fakultas Ekonomi dan Bisnis Jurusan Manajemen Universitas Putra Indonesia YTPK Padang). Jurnal Ekonomi Bisnis dan Teknologi (EKOBISTEK), IX(1), pp. 63-71. 